\title{
Lipid rafts: linking prion protein to zinc transport and amyloid- $\beta$ toxicity in Alzheimer's disease
}

\author{
Nicole T. Watt ${ }^{1}$, Heledd H. Griffiths ${ }^{2}$ and Nigel M. Hooper ${ }^{2 *}$ \\ ' Division of Cardiovascular and Diabetes Research, Multidisciplinary Cardiovascular Research Centre, University of Leeds, Leeds, UK \\ ${ }^{2}$ Faculty of Medical and Human Sciences, Institute of Brain, Behaviour and Mental Health, University of Manchester, Manchester, UK
}

\section{Edited by:}

Sophie Mouillet-Richard, INSERM

Unit 1124, France

\section{Reviewed by:}

NADIA ALFAIDY, INSERM, France Gerold Schmitt-Ulms, University of Toronto, Canada

\section{${ }^{*}$ Correspondence:}

Nigel M. Hooper, Faculty of Medical and Human Sciences, Institute of Brain, Behaviour and Mental Health, University of Manchester, Rm 2.015 AV Hill Building, Oxford Road, Manchester M13 9PT, UK e-mail: nigel.hooper@ manchester.ac.uk
Dysregulation of neuronal zinc homeostasis plays a major role in many processes related to brain aging and neurodegenerative diseases, including Alzheimer's disease (AD). Yet, despite the critical role of zinc in neuronal function, the cellular mechanisms underpinning its homeostatic control are far from clear. We reported that the cellular prion protein $(\operatorname{Pr} P C)$ is involved in the uptake of zinc into neurons. This $\operatorname{PrP}^{\mathrm{C}}$-mediated zinc influx required the metal-binding octapeptide repeats in $\operatorname{PrP}^{\mathrm{C}}$ and the presence of the zinc permeable AMPA channel with which $\operatorname{PrPC}$ directly interacted. Together with the observation that $\operatorname{PrPC}$ is evolutionarily related to the ZIP family of zinc transporters, these studies indicate that $\mathrm{PrPC}^{\mathrm{C}}$ plays a key role in neuronal zinc homeostasis. Therefore, $\mathrm{PrPC}^{\mathrm{C}}$ could contribute to cognitive health and protect against age-related zinc dyshomeostasis but $\operatorname{PrPC}^{\mathrm{C}}$ has also been identified as a receptor for amyloid- $\beta$ oligomers which accumulate in the brains of those with AD. We propose that the different roles that $\operatorname{PrPC}^{C}$ has are due to its interaction with different ligands and/or co-receptors in lipid raft-based signaling/transport complexes.

Keywords: Alzheimer's disease, AMPA receptor, amyloid, cholesterol, prion protein, zinc

\section{ZINC HOMEOSTASIS AND ALZHEIMER'S DISEASE}

Zinc is a trace element that is essential for life and whose importance to the function of the central nervous system is increasingly being appreciated. Zinc serves as a cofactor for $>300$ enzymes that regulate a variety of cellular processes and signaling pathways, and is also a key structural component of numerous other proteins (Frederickson et al., 2005; Sensi et al., 2009). In the brain, which has one of the highest zinc contents with respect to other organs, zinc-containing axons are particularly abundant in the hippocampus and cortex (Toth, 2011). Zinc is predominantly, but not exclusively, localized within synaptic vesicles at glutamatergic nerve terminals [sometimes referred to as gluzinergic neurons (Mocchegiani et al., 2005)]. During neuronal activity, zinc is released along with glutamate into the synaptic cleft where it affects the activity of various receptors. In addition, zinc is itself a signaling molecule, and within the neuron it regulates the activity of multiple enzymes and plays a critical role in the formation and stabilization of the postsynaptic density (Beyersmann and Haase, 2001; Grabrucker et al., 2011; Wilson et al., 2012). Both intracellular and extracellular zinc concentrations must be tightly maintained within narrow optimal ranges for the correct functioning of the nervous system. An excess influx of zinc can damage postsynaptic neurons (Plum et al., 2010) and zinc deficiency affects neurogenesis and increases neuronal apoptosis, which can lead to learning and memory deficits (Szewczyk, 2013). Under normal circumstances, zinc homeostasis is maintained by the coordinated actions of a range of different proteins involved in its uptake, efflux, and intracellular storage and trafficking. Zinc enters neurons through members of the ZIP (Zrt/Irt-like Protein; SLC39) family of zinc transporters, as well as through activated voltage-gated $\mathrm{Ca}^{2+}$ channels, $\alpha$-amino3-hydroxy-5-methyl-4-isoxazoleproprionate (AMPA) receptors, and N-methyl-D-aspartate (NMDA) receptors (Cousins et al., 2006; Sensi et al., 2009). Zinc exporters, members of the zinc transporter (ZnT; SLC30) family transport zinc from the cytosol to the lumen of intracellular organelles or out of the cell (Sensi et al., 2009).

Alzheimer's disease (AD) is the most prevalent form of dementia, affecting millions of individuals world-wide. With currently no cure, the economic and social costs associated with the disease are set to increase dramatically with our aging population. $\mathrm{AD}$ is characterized by the deposition in the brain of extracellular plaques of amyloid- $\beta$ (A $\beta$ ) peptide and intracellular inclusions of tau protein. $A \beta$ is proteolytically cleaved from the larger amyloid precursor protein (APP), and both $A \beta$ and APP have binding sites for zinc (Watt et al., 2010; Wong et al., 2014). Zinc, particularly that released from glutamatergic nerve terminals, has a crucial role to play in the aggregation of $A \beta$ into neurotoxic oligomers and fibrils (Bush et al., 1994; Esler et al., 1996; Deshpande et al., 2009), and is also co-localized with $A \beta$ in amyloid plaques (Dong et al., 2003). The activity of the zinc transporter ZnT-3 is required for the transport of zinc into the glutamate-containing presynaptic vesicles. Key evidence for a link between zinc and amyloid pathology in $\mathrm{AD}$ comes from the crossing of ZnT-3 knockout mice with Tg2576 mice, a commonly used transgenic mouse model of AD. The crossed mice had minimal synaptic zinc and as a consequence both brain plaque load and amyloid angiopathy were significantly reduced (Lee et al., 2002; Friedlich et al., 2004). Furthermore, in a separate study of aged ZnT-3 knockout mice, there were marked 
differences in learning and memory observed compared to wild type mice, supporting a requirement for zinc in memory function and the maintenance of synaptic health upon aging (Adlard et al., 2010).

\section{PrPC AND NEURONAL ZINC UPTAKE}

Recently we reported that $\operatorname{PrP}^{\mathrm{C}}$ facilitates the uptake of zinc into neuronal cells (Watt et al., 2012). $\mathrm{PrP}^{\mathrm{C}}$ is infamous because of its conformational conversion into $\mathrm{PrP}^{\mathrm{Sc}}$ being responsible for the fatal transmissible spongiform encephalopathies, such as Creutzfeldt-Jakob disease. $\mathrm{PrP}^{\mathrm{C}}$ is a glycosyl-phosphatidylinositol (GPI)-anchored protein located on the surface of neurons, at both pre- and post-synaptic sites. It is found throughout the central nervous system and is particularly abundant in the hippocampus and frontal cortex (Sales et al., 1998). Using two zinc specific fluorescent dyes (Newport green and Zinpyr-1) we showed that $\mathrm{PrP}^{\mathrm{C}}$ enhanced the uptake of zinc into human SH-SY5Y neuroblastoma cells and rat primary hippocampal neurons (Watt et al., 2012). This $\operatorname{PrP}^{\mathrm{C}}$-mediated zinc influx required the metalbinding octapeptide repeat region in $\mathrm{PrP}^{\mathrm{C}}$ but not its endocytosis. We then used selective channel antagonists to identify that AMPA receptors were involved in the $\operatorname{PrP}^{\mathrm{C}}$-mediated zinc uptake, and that $\mathrm{PrP}^{\mathrm{C}}$ interacted with both GluA1 and GluA2 AMPA receptor subunits as shown by co-immunoprecipitation. Intracellular protein tyrosine phosphatase activity, which is potently inhibited by zinc (Brautigan et al., 1981; Wilson et al., 2012), was increased in the brains of $\mathrm{PrP}^{\mathrm{C}}$ null mice, providing evidence of a physiological consequence of altered zinc uptake in the absence of $\operatorname{PrP}^{\mathrm{C}}$. These observations provided the first mechanistic explanation for the reduced zinc in the hippocampus and other brain regions of $\operatorname{PrP}^{\mathrm{C}}$ null mice (Pushie et al., 2011) and indicate that $\operatorname{PrP}^{\mathrm{C}}$ is a key player in neuronal zinc uptake.
Interestingly, during the course of our work showing that $\operatorname{PrP}^{\mathrm{C}}$ mediates neuronal zinc uptake, the protein was reported to be evolutionarily related to a subset of the ZIP family of zinc transporters (Schmitt-Ulms et al., 2009). Bioinformatic analysis revealed that the $\mathrm{N}$-terminal extracellular domain of a distinct sub-branch of the LIV-1 subfamily of ZIPs that includes ZIPs 5,6 , and 10 had sequence similarity to the C-terminal globular domain of $\mathrm{PrP}^{\mathrm{C}}$. These three ZIPs are also equipped with histidine-rich sequences N-terminal to their "prion-like" domain, capable of divalent metal binding, which is reminiscent of the octapeptide repeat domain of $\operatorname{PrP}^{\mathrm{C}}$ (Figure 1A). Interestingly, the orientation and distance of the "prion-like" domain to the respective membrane attachment sites in both $\mathrm{PrP}^{\mathrm{C}}$ and the ZIPs are similar (Figure 1A), and the primary sequence of the first transmembrane domain in the ZIPs and the GPI anchor attachment sequence of $\mathrm{PrP}^{\mathrm{C}}$ are also comparable, providing further evidence that $\mathrm{PrP}^{\mathrm{C}}$ is evolutionarily related to members of the ZIP family (Schmitt-Ulms et al., 2009).

As $\mathrm{PrP}^{\mathrm{C}}$ is a GPI-anchored protein residing in the outer leaflet of the plasma membrane, in order to correlate a function for $\mathrm{PrP}^{\mathrm{C}}$ in the transport of zinc across the lipid bilayer, we proposed that $\operatorname{PrP}^{\mathrm{C}}$ requires the assistance of the channel properties of another protein(s), such as AMPA receptors, in order to achieve zinc transport (Figure 1B) (Watt et al., 2012). The octapeptide repeats in the GPI-anchored $\mathrm{PrP}^{\mathrm{C}}$ act as a zinc sensor/scavenger in the extracellular environment which then presents the metal to the transmembrane channel for uptake of the zinc into the cell (Watt et al., 2013). Interestingly, not all ZIP family members have an extracellular N-terminal extension that may function in zinc sensing: for example ZIPs 1, 2, 3, 9, and 11 have minimal N-terminal extensions on the first transmembrane domain. This raises the intriguing possibility that the two properties (zinc
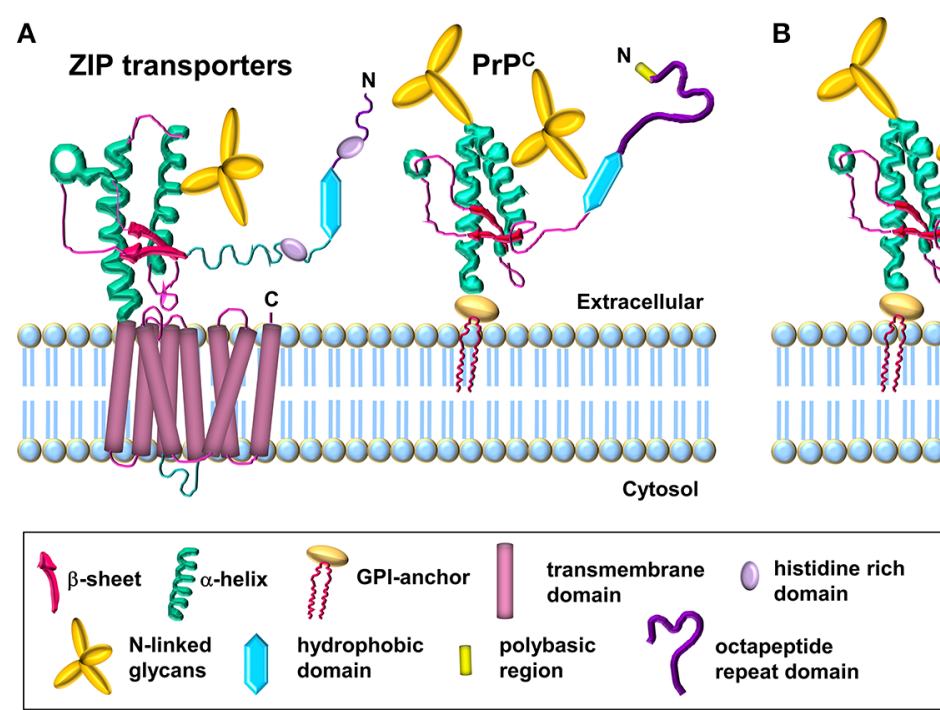

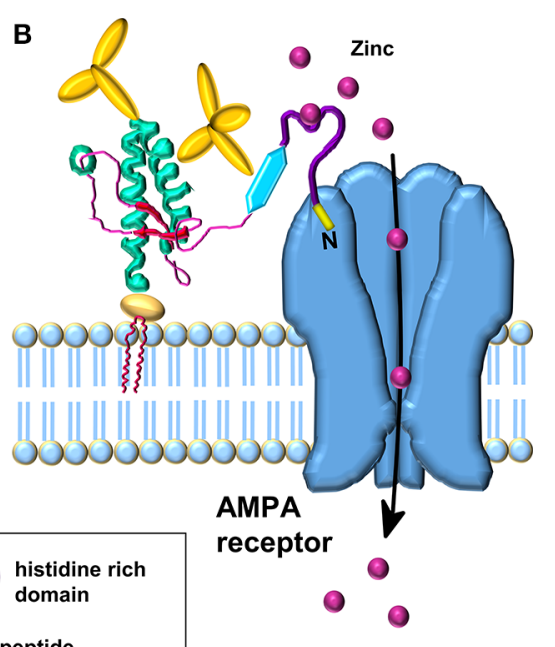

low affinity binding of zinc to the octapeptide repeats. The $\mathrm{N}$-terminal polybasic region of $\mathrm{PrPC}^{\mathrm{C}}$ interacts with the AMPA receptor subunits; this interaction facilitates the transport of zinc through the AMPA receptor which forms a channel across the membrane for the uptake of zinc in a manner similar to the C-terminal region of the ZIP transporter. Modified from Watt et al. (2013). 
sensing and zinc channel) present together in certain ZIPs (e.g., ZIPs 6 and 10) reside in separate proteins in those ZIPs with minimal N-terminal extensions. It will be interesting to see if $\mathrm{PrP}^{\mathrm{C}}$ acts as the zinc sensor in combination with certain ZIPs, similar to the situation we have proposed for $\mathrm{PrP}^{\mathrm{C}}$ and the AMPA receptor (Figure 1B) (Watt et al., 2012, 2013). Such PrPC-based zinc sensing modules may be restricted to higher eukaryotes in which $\operatorname{PrP}^{\mathrm{C}}$ with the octapeptide metal binding repeats is present.

In addition to its role in zinc metabolism, $\operatorname{PrP}^{\mathrm{C}}$ also plays a role in the homeostasis of other metals such as iron and copper (Kozlowski et al., 2010; Singh et al., 2014). $\operatorname{PrP}^{\mathrm{C}}$ expression alters regional zinc, copper and iron content in the mouse brain (Pushie et al., 2011) and there appears to be crosstalk between the different metals, with zinc modulating copper coordination to the octapeptide repeats (Stellato et al., 2011). In addition, $\mathrm{PrP}^{\mathrm{C}}$ modulates NMDA receptor activity in a copper-dependent manner (Stys et al., 2012), suggesting that multiple receptors/channels may be regulated by $\mathrm{PrP}^{\mathrm{C}}$ in a ligand/metal-dependent manner.

\section{A CELL-SURFACE, LIPID RAFT-BASED COMPLEX INVOLVED IN THE REGULATION OF ZINC UPTAKE}

The GPI-anchored $\mathrm{PrP}^{\mathrm{C}}$ is localized in cholesterol-rich, detergent-resistant lipid rafts at the cell surface (Taylor et al., 2005) and it has been proposed that $\operatorname{PrP}^{\mathrm{C}}$ functions as a key scaffolding protein for the dynamic assembly of cell surface signaling modules (Linden et al., 2008). $\operatorname{PrP}^{\mathrm{C}}$, along with the microdomain-forming flotillin or caveolin proteins, may lead to the local assembly of membrane protein complexes at sites involved in cellular communication, such as cell-cell contacts, focal adhesions, the T-cell cap and synapses (Solis et al., 2010). Lipid rafts are essential for synapse development, stabilization and maintenance and caveolin-1 organizes and targets synaptic components to rafts (Hering et al., 2003; Willmann et al., 2006; Guirland and Zheng, 2007). Interestingly, when ZIP1 and ZIP3 were stably expressed in HEK293 cells, the punctate cell surface staining observed led the authors to suggest that they were localized to lipid rafts (although no experimental evidence for this was provided) (Wang et al., 2004). Furthermore, treatment of the HEK293 cells with methyl- $\beta$-cyclodextrin, which sequesters cholesterol and disrupts cholesterol-rich lipid rafts, resulted in a more diffuse surface staining (Wang et al., 2004), reminiscent of what is observed for $\mathrm{PrP}^{\mathrm{C}}$ and other GPI-anchored proteins (Parkin et al., 2003; Taylor et al., 2005). We also have disrupted rafts in neuronal cells using methyl- $\beta$-cyclodextrin and observed a reduction in zinc uptake, an effect exacerbated when the cells also expressed $\operatorname{PrP}^{\mathrm{C}}$ (Watt and Hooper, unpublished). In contrast, it has been reported that ZIP10 only partially colocalizes with $\mathrm{PrP}^{\mathrm{C}}$ in $\mathrm{N} 2 \mathrm{a}$ cells and is not detected in detergent-resistant rafts (Ehsani et al., 2012). These data raise the intriguing possibility that a cell-surface, lipid raft-based complex, possibly stabilized by $\operatorname{PrP}^{\mathrm{C}}$, regulates the cell surface expression of certain zinc transporters and thus zinc uptake.

\section{PrPC IS A CELL SURFACE RECEPTOR FOR A $\beta$ OLIGOMERS}

In $2009, \mathrm{PrP}^{\mathrm{C}}$ was identified as a high-affinity receptor for $\mathrm{A} \beta$ oligomers, the primary neurotoxic species in $\mathrm{AD}$ (Lauren et al., 2009). The presence of $\operatorname{PrP}^{C}$ in hippocampal slices was shown to be responsible for the $A \beta$ oligomer-mediated inhibition of long-term potentiation (LTP) (Lauren et al., 2009). $\operatorname{PrP}^{\mathrm{C}}$ was also required for the manifestation of memory impairments in an $\mathrm{AD}$ mouse model (Gimbel et al., 2010), which were reversed by intracerebral infusion of an anti- $\mathrm{PrP}^{\mathrm{C}}$ monoclonal antibody (Chung et al., 2010). Immuno-targeting of $\operatorname{PrP}^{\mathrm{C}}$ was shown to block completely the LTP impairments caused by A $\beta$ oligomers derived from human AD brain extracts (Barry et al., 2011; Freir et al., 2011). $\mathrm{A} \beta$ oligomers bound to $\mathrm{PrP}^{\mathrm{C}}$ activate the non-receptor tyrosine kinase Fyn (Um et al., 2012; Rushworth et al., 2013) and results in pathological changes in tau (Larson et al., 2012). Although there is general consensus that $\mathrm{PrP}^{\mathrm{C}}$ can bind oligomeric forms of $\mathrm{A} \beta$, some studies dispute a role for $\mathrm{PrP}^{\mathrm{C}}$ in mediating $\mathrm{A} \beta$ toxicity (Calella et al., 2010; Kessels et al., 2010).

It has been hypothesized that a putative transmembrane coreceptor is required to connect the binding of $A \beta$ to the GPIanchored $\mathrm{PrP}^{\mathrm{C}}$ on the outer surface of the plasma membrane with downstream effects inside the cell (Cisse and Mucke, 2009; Lauren et al., 2009). The transmembrane low-density lipoproteinreceptor related protein-1 (LRP1) is highly expressed in neuronal cells (Nykjaer and Willnow, 2002), facilitates the endocytosis of $\operatorname{PrP}^{\mathrm{C}}$ (Taylor and Hooper, 2007) and has been implicated in the neuronal uptake of $\mathrm{A} \beta$ (Fuentealba et al., 2010; Kanekiyo et al., 2011). We hypothesized, therefore, that LRP1 may play a role in the $\operatorname{PrP}^{\mathrm{C}}$-mediated action of $\mathrm{A} \beta$ oligomers (Figure 2 ). We showed that LRP1 is required for the binding of $A \beta$ oligomers to cells, as well as for their subsequent internalization and cytotoxicity (Rushworth et al., 2013). In parallel with our work on LRP1, Strittmatter and colleagues identified the metabotropic glutamate receptor, mGluR5, as a co-receptor with $\mathrm{PrP}^{\mathrm{C}}$ for $\mathrm{A} \beta$ oligomers and was required to activate Fyn (Um et al., 2013). Furthermore, antagonists of mGluR5 reversed the deficits in learning, memory and synapse density in $\mathrm{AD}$ transgenic mice (Um et al., 2013). In addition, the $\mathrm{A} \beta$-PrP $\mathrm{P}^{\mathrm{C}}$-mGluR5 interplay is involved in mediating both long-term depression facilitation and LTP inhibition (Hu et al., 2014). Thus, both LRP1 and mGluR5 appear to be transmembrane co-receptors in the $\mathrm{A} \beta-\mathrm{PrP}^{\mathrm{C}}$ interaction, which are required for the $\mathrm{PrP}^{\mathrm{C}}$-mediated action of $\mathrm{A} \beta$ oligomers. Whether both LRP1 and mGluR5 reside in the same complex with $\mathrm{PrP}^{\mathrm{C}}$ or in separate signaling complexes is currently unclear.

\section{A CELL-SURFACE, LIPID RAFT-BASED SIGNALING COMPLEX INVOLVED IN A $\beta$ OLIGOMER ACTION}

Cell surface cholesterol-rich, detergent-resistant lipid rafts are intimately involved in the production, aggregation and toxicity of $\mathrm{A} \beta$ (Rushworth and Hooper, 2010; Di Paolo and Kim, 2011). For example, these membrane microdomains have been linked with $A \beta$ toxicity via Fyn, and rafts are involved in the neuronal internalization of $A \beta$ (Williamson et al., 2008; Lai and McLaurin, 2010). We investigated whether the integrity of lipid rafts is required for the binding of $A \beta$ oligomers and the subsequent activation of Fyn. Treatment of cells with methyl$\beta$-cyclodextrin caused the re-localization of $\mathrm{PrP}^{\mathrm{C}}$ and Fyn from detergent-resistant rafts to detergent-soluble, non-raft regions of the membrane as analyzed by sucrose density gradient centrifugation in the presence of Triton X-100. Surprisingly, disruption of the rafts with methyl- $\beta$-cyclodextrin significantly reduced (by 


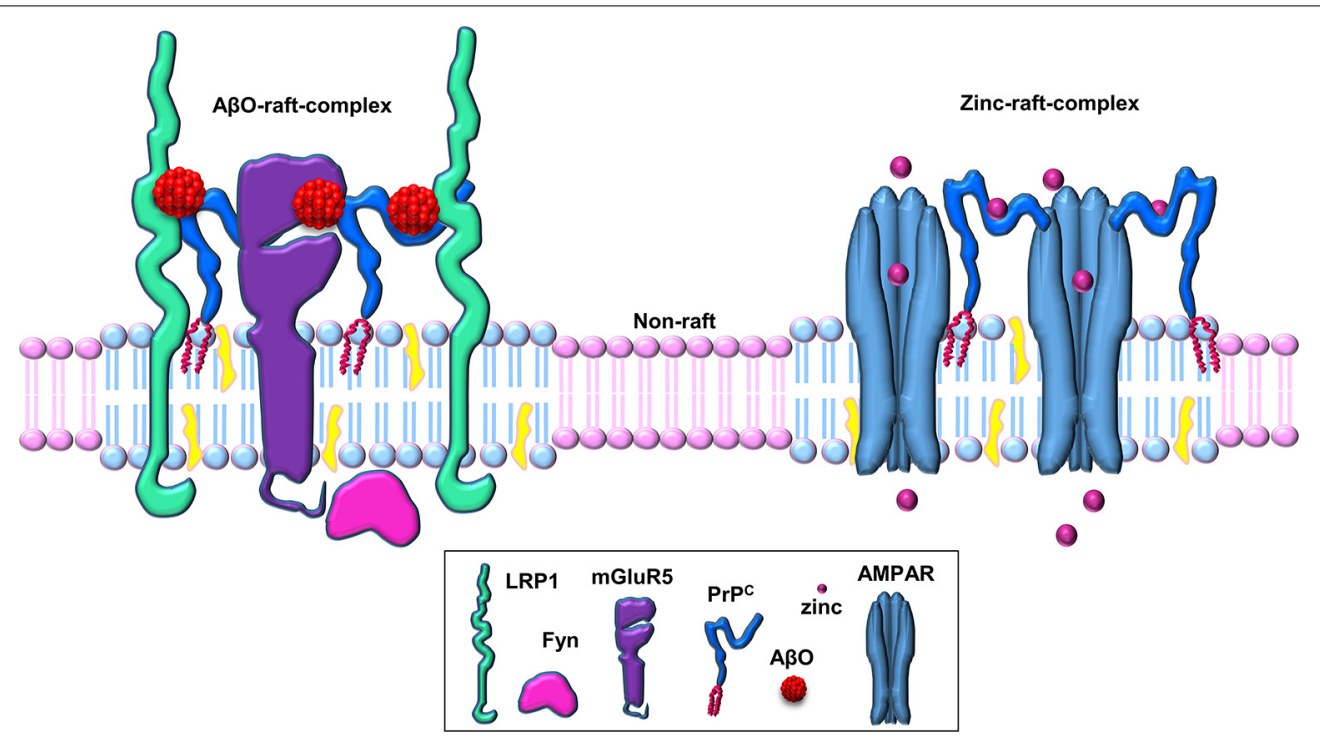

FIGURE 2 | Schematic of PrPC-based cell-surface, raft-based complexes involved in zinc uptake and $\mathbf{A} \boldsymbol{\beta}$ binding. $\mathrm{Pr}^{\mathrm{C}}$ acts as a hub for cell surface, lipid raft-based signaling/transport complexes. $\operatorname{PrPC}$ associates with various transmembrane proteins (such as AMPA receptors, LRP1, mGluR5, etc.) in these multi-protein complexes in a ligand-dependent manner (here shown for the ligands zinc and $A \beta$ oligomers within separate raft-based complexes).
$80.6 \%$ ) the cell surface binding of the $A \beta$ oligomers, even though the cell surface expression of $\operatorname{PrP}^{\mathrm{C}}$ was unaffected, and prevented the $A \beta$ oligomers from activating Fyn (Rushworth et al., 2013). Thus, raft localization of $\mathrm{PrP}^{\mathrm{C}}$ is required for the binding of $\mathrm{A} \beta$ oligomers, and the integrity of rafts and/or other raft-localized proteins are required for the $A \beta$-mediated activation of Fyn. These observations suggest that there is a cell-surface, raft-based signaling complex that is key to the binding of $A \beta$ oligomers and the subsequent generation of cellular responses.

$\mathrm{A} \beta$ oligomers caused mGluR5 receptors to manifest reduced lateral diffusion as they became aberrantly clustered (Renner et al., 2010). Antibodies against $\operatorname{PrP}^{\mathrm{C}}$ and the NR1 subunit of NMDA receptors had a similar inhibitory effect on $A \beta$ oligomer binding as the antibody against mGluR5, but there was not an additive effect of the individual antibodies, suggesting that mGluR5, PrPC , and NR1 may be in proximity to each other as well as the $A \beta$ oligomer binding site (Renner et al., 2010). Interestingly, addition of $A \beta$ oligomers to neurons caused a large increase of mGluR5 in the Triton-resistant fraction (Renner et al., 2010), although no link to its possible redistribution into detergentresistant lipid rafts was made. In another study, disruption of lipid rafts by cholesterol depletion reduced the interaction of $A \beta$ with $\alpha$-7-nicotinic acetylcholine receptors (Khan et al., 2010). These observations are consistent with multiple (co)receptor proteins for $\mathrm{A} \beta$ oligomers residing in cell-surface, raft-based complex(es).

\section{PrPC AND RAFTS ARE DYSREGULATED IN AGING}

Zinc homeostasis plays a major role in many processes related to brain aging. For example, mouse models of accelerated aging, such as senescence-accelerated mouse prone 10 (SAMP10) mice display a low total zinc concentration in synaptic vesicles that is associated with brain atrophy and defects in learning and memory (Saito et al., 2000), and dietary zinc deficiency influences hippocampal learning and memory in an age-dependent manner (Mocchegiani et al., 2005; Szewczyk, 2013). ZIP6 expression has been reported to be decreased in an age-dependent manner (Wong et al., 2013), although nothing has been reported about the expression, subcellular localization or function of any other ZIP in the aged brain. Caveolin-1 has been identified as a novel control point for healthy neuronal aging, with the localization of caveolin-1, PSD95, and AMPA receptors in lipid rafts being decreased in aged ( $>18$ months) mice compared with young (3-6 month) mice (Head et al., 2010). Furthermore, in an aging series (age 20-88 years) of human brains we reported that $\operatorname{PrP}^{\mathrm{C}}$ was reduced in the hippocampus with increasing age (Whitehouse et al., 2010). Preliminary data indicate that there is a significant reduction of both ZIP1 and ZIP3 in the hippocampus of old (7988 years) compared with young (20-26 years) individuals (Watt and Hooper, unpublished). These observations suggest that alterations to the structure and function of the cell-surface, raft-based zinc transporter complex may occur in aging and contribute to the age-related dysregulated zinc homeostasis.

Aging is the greatest risk factor for $\mathrm{AD}$ and recently the REST protein was reported to have a central role in protecting aging neurons from degeneration (Lu et al., 2014). There is a close relationship between lipid rafts, cholesterol, and the age-associated decline and dysregulation of cellular signaling pathways (OhnoIwashita et al., 2010). A key component of a subset of rafts, caveolin-1, was identified as a novel control point for both $A \beta$ based neurodegeneration and healthy neuronal aging (Head et al., 2010), and caveolin-1 expression is altered in AD (Gaudreault et al., 2004). In addition, the level of $\mathrm{PrP}^{\mathrm{C}}$ is altered in both the AD and aging brain (Whitehouse et al., 2010, 2013; Larson et al., 2012). Thus, dysregulation of the structure and function of cell-surface, raft-based signaling complexes may occur in, and contribute to, both $\mathrm{AD}$ and aging. 


\section{CONCLUSION}

$\mathrm{PrP}^{\mathrm{C}}$ appears to be involved in multiple physiological and pathological processes, including as highlighted here, neuronal zinc uptake and $A \beta$ oligomer binding and toxicity. We propose that $\mathrm{PrP}^{\mathrm{C}}$ acts as a hub for cell surface, lipid raft-based signaling/transport complexes, and that the different roles that the protein has are due to the selective interaction of $\operatorname{PrP}^{\mathrm{C}}$ with different ligands (such as zinc or A $\beta$ oligomers) and/or co-receptors (such as AMPA receptors, LRP1, mGluR5) in these multi-protein complexes (Figure 2). It is likely that these complexes are relatively transient in nature, being stabilized upon binding of a particular ligand for a limited time period before dissociation or endocytosis terminates the signaling or transport process. The use of more sophisticated techniques, such as super resolution light microscopy, should enable the molecular details of these different lipid raft-based signaling/transport complexes to be determined and provide a clearer picture of the role of $\mathrm{PrP}^{\mathrm{C}}$ and lipid rafts in neuronal zinc transport and $\mathrm{A} \beta$ action in $\mathrm{AD}$. It will also be interesting to determine how the interplay between $\operatorname{PrP}^{\mathrm{C}}$, zinc, and $\mathrm{A} \beta$ may underlie aging and age-related diseases.

\section{ACKNOWLEDGMENTS}

The authors acknowledge the financial support of the Medical Research Council of Great Britain (G0802189).

\section{REFERENCES}

Adlard, P. A., Parncutt, J. M., Finkelstein, D. I., and Bush, A. I. (2010). Cognitive loss in zinc transporter-3 knock-out mice: a phenocopy for the synaptic and memory deficits of Alzheimer's disease? J. Neurosci. 30, 1631-1636. doi: 10.1523/JNEUROSCI.5255-09.2010

Barry, A. E., Klyubin, I., McDonald, J. M., Mably, A. J., Farrell, M. A., Scott, M., et al. (2011). Alzheimer's disease brain-derived amyloid- $\beta$-mediated inhibition of LTP in vivo is prevented by immunotargeting cellular prion protein. J. Neurosci. 31, 7259-7263. doi: 10.1523/JNEUROSCI.6500-10.2011

Beyersmann, D., and Haase, H. (2001). Functions of zinc in signaling, proliferation and differentiation of mammalian cells. Biometals 14, 331-341. doi: 10.1023/A:1012905406548

Brautigan, D. L., Bornstein, P., and Gallis, B. (1981). Phosphotyrosyl-protein phosphatase. Specific inhibition by Zn. J. Biol. Chem. 256, 6519-6522.

Bush, A. I., Pettingell, W. H., Multhaup, G., d Paradis, M., Vonsattel, J. P., Gusella, J. F., et al. (1994). Rapid induction of Alzheimer $A \beta$ amyloid formation by zinc. Science 265, 1464-1467. doi: 10.1126/science.8073293

Calella, A. M., Farinelli, M., Nuvolone, M., Mirante, O., Moos, R., Falsig, J., et al. (2010). Prion protein and A $\beta$-related synaptic toxicity impairment. EMBO Mol. Med. 2, 306-314. doi: 10.1002/emmm.201000082

Chung, E., Ji, Y., Sun, Y., Kascsak, R. J., Kascsak, R. B., Mehta, P. D., et al. (2010). Anti-PrPC monoclonal antibody infusion as a novel treatment for cognitive deficits in an Alzheimer's disease model mouse. BMC Neurosci. 11:130. doi: 10.1186/1471-2202-11-130

Cisse, M., and Mucke, L. (2009). Alzheimer's disease: a prion protein connection. Nature 457, 1090-1091. doi: 10.1038/4571090a

Cousins, R. J., Liuzzi, J. P., and Lichten, L. A. (2006). Mammalian zinc transport, trafficking, and signals. J. Biol. Chem. 281, 24085-24089. doi: 10.1074/jbc. R600011200

Deshpande, A., Kawai, H., Metherate, R., Glabe, C. G., and Busciglio, J. (2009). A role for synaptic zinc in activity-dependent $A \beta$ oligomer formation and accumulation at excitatory synapses. J. Neurosci. 29, 4004-4015. doi: 10.1523/JNEUROSCI.5980-08.2009

Di Paolo, G., and Kim, T.-W. (2011). Linking lipids to Alzheimer's disease: cholesterol and beyond. Nat. Rev. Neurosci. 12, 284-296. doi: 10.1038/nrn3012

Dong, J., Atwood, C. S., Anderson, V. E., Siedlak, S. L., Smith, M. A., Perry, G., et al. (2003). Metal binding and oxidation of amyloid- $\beta$ within isolated senile plaque cores: Raman microscopic evidence. Biochemistry 42, 2768-2773. doi: 10.1021/bi0272151
Ehsani, S., Salehzadeh, A., Huo, H., Reginold, W., Pocanschi, C. L., Ren, H., et al. (2012). LIV-1 ZIP ectodomain shedding in prion-infected mice resembles cellular response to transition metal starvation. J. Mol. Biol. 422, 556-574. doi: 10.1016/j.jmb.2012.06.003

Esler, W. P., Stimson, E. R., Jennings, J. M., Ghilardi, J. R., Mantyh, P. W., and Maggio, J. E. (1996). Zinc-induced aggregation of human and rat $\beta$ amyloid peptides in vitro. J. Neurochem. 66, 723-732. doi: 10.1046/j.14714159.1996.66020723.x

Frederickson, C. J., Koh, J. Y., and Bush, A. I. (2005). The neurobiology of zinc in health and disease. Nat. Rev. Neurosci. 6, 449-462. doi: 10.1038/nrn1671

Freir, D. B., Nicoll, A. J., Klyubin, I., Panico, S., McDonald, J. M., Risse, E., et al. (2011). Interaction between prion protein and toxic amyloid $\beta$ assemblies can be therapeutically targeted at multiple sites. Nat. Commun. 2, 336. doi: $10.1038 /$ ncomms 1341

Friedlich, A. L., Lee, J. Y., van Groen, T., Cherny, R. A., Volitakis, I., Cole, T. B., et al. (2004). Neuronal zinc exchange with the blood vessel wall promotes cerebral amyloid angiopathy in an animal model of Alzheimer's disease. J. Neurosci. 24, 3453-3459. doi: 10.1523/JNEUROSCI.0297-04.2004

Fuentealba, R. A., Liu, Q., Zhang, J., Kanekiyo, T., Hu, X., Lee, J. M., et al. (2010). Low-density lipoprotein receptor-related protein 1 (LRP1) mediates neuronal A $\beta 42$ uptake and lysosomal trafficking. PLOS ONE 5:e11884. doi: 10.1371/journal.pone.0011884

Gaudreault, S. B., Dea, D., and Poirier, J. (2004). Increased caveolin-1 expression in Alzheimer's disease brain. Neurobiol. Aging 25, 753-759. doi: 10.1016/j.neurobiolaging.2003.07.004

Gimbel, D. A., Nygaard, H. B., Coffey, E. E., Gunther, E. C., Lauren, J., Gimbel, Z. A., et al. (2010). Memory impairment in transgenic Alzheimer mice requires cellular prion protein. J. Neurosci. 30, 6367-6374. doi: 10.1523/JNEUROSCI.039510.2010

Grabrucker, A. M., Knight, M. J., Proepper, C., Bockmann, J., Joubert, M., Rowan, M., et al. (2011). Concerted action of zinc and ProSAP/Shank in synaptogenesis and synapse maturation. EMBO J. 30, 569-581. doi: 10.1038/emboj.2010.336

Guirland, C., and Zheng, J. Q. (2007). Membrane lipid rafts and their role in axon guidance. Adv. Exp. Med. Biol. 621, 144-155. doi: 10.1007/978-0-38776715-4_11

Head, B. P., Peart, J. N., Panneerselvam, M., Yokoyama, T., Pearn, M. L., Niesman, I. R., et al. (2010). Loss of caveolin-1 accelerates neurodegeneration and aging. PloS ONE 5:e15697. doi: 10.1371/journal.pone.0015697

Hering, H., Lin, C. C., and Sheng, M. (2003). Lipid rafts in the maintenance of synapses, dendritic spines, and surface AMPA receptor stability. J. Neurosci. 23, 3262-3271.

Hu, N.-W., Nicoll, A. J., Zhang, D., Mably, A. J., O'Malley, T., Purro, S. A., et al. (2014). mGlu5 receptors and cellular prion protein mediate amyloid- $\beta$ facilitated synaptic long-term depression in vivo. Nat. Commun. 5:3374. doi: $10.1038 /$ ncomms4374

Kanekiyo, T., Zhang, J., Liu, Q., Liu, C.-C., Zhang, L., and Bu, G. (2011). Heparan sulphate proteoglycan and the low-density lipoprotein receptor-related protein 1 constitute major pathways for neuronal amyloid- $\beta$ uptake. J. Neurosci. 31, 1644-1651. doi: 10.1523/JNEUROSCI.5491-10.2011

Kessels, H. W., Nguyen, L. N., Nabavi, S., and Malinow, R. (2010). The prion protein as a receptor for amyloid- $\beta$. Nature 466, E3-E4; discussion: E4-E5. doi: 10.1038/nature09217

Khan, G. M., Tong, M., Jhun, M., Arora, K., and Nichols, R. A. (2010). $\beta$-Amyloid activates presynaptic $\alpha 7$ nicotinic acetylcholine receptors reconstituted into a model nerve cell system: involvement of lipid rafts. Eur. J. Neurosci. 31, 788-796. doi: 10.1111/j.1460-9568.2010.07116.x

Kozlowski, H., Luczkowski, M., and Remelli, M. (2010). Prion proteins and copper ions. Biological and chemical controversies. Dalton Trans. 39, 6371-6385. doi: $10.1039 / \mathrm{c} 001267 \mathrm{j}$

Lai, A. Y., and McLaurin, J. (2010). Mechanisms of amyloid- $\beta$ peptide uptake by neurons: the role of lipid rafts and lipid raft-associated proteins. Int. J. Alzheimers Dis. 2011:548380. doi: 10.4061/2011/548380

Larson, M., Sherman, M. A., Amar, F., Nuvolone, M., Schneider, J. A., Bennett, D. A., et al. (2012). The complex PrPc-Fyn couples human oligomeric A $\beta$ with pathological Tau changes in Alzheimer's disease. J. Neurosci. 32, 16857-16871. doi: 10.1523/JNEUROSCI.1858-12.2012

Lauren, J., Gimbel, D. A., Nygaard, H. B., Gilbert, J. W., and Strittmatter, S. M. (2009). Cellular prion protein mediates impairment of synaptic plasticity by amyloid- $\beta$ oligomers. Nature 457, 1128-1132. doi: 10.1038/nature07761 
Lee, J. Y., Cole, T. B., Palmiter, R. D., Suh, S. W., and Koh, J. Y. (2002). Contribution by synaptic zinc to the gender-disparate plaque formation in human Swedish mutant APP transgenic mice. Proc. Natl. Acad. Sci. U.S.A. 99, 7705-7710. doi: 10.1073/pnas.092034699

Linden, R., Martins, V. R., Prado, M. A., Cammarota, M., Izquierdo, I., and Brentani, R. R. (2008). Physiology of the prion protein. Physiol. Rev. 88, 673-728. doi: 10.1152/physrev.00007.2007

Lu, T., Aron, L., Zullo, J., Pan, Y., Kim, H., Chen, Y., et al. (2014). REST and stress resistance in ageing and Alzheimer's disease. Nature 507, 448-454. doi: 10.1038 /nature 13163

Mocchegiani, E., Bertoni-Freddari, C., Marcellini, F., and Malavolta, M. (2005). Brain, aging and neurodegeneration: role of zinc ion availability. Prog. Neurobiol. 75, 367-390. doi: 10.1016/j.pneurobio.2005.04.005

Nykjaer, A., and Willnow, T. E. (2002). The low-density lipoprotein receptor gene family: a cellular Swiss army knife? Trends Cell Biol. 12, 273-280. doi: 10.1016/S0962-8924(02)02282-1

Ohno-Iwashita, Y., Shimada, Y., Hayashi, M., and Inomata, M. (2010). Plasma membrane microdomains in aging and disease. Geriatr. Gerontol. Int. 10 Suppl. 1, S41-S52. doi: 10.1111/j.1447-0594.2010.00600.x

Parkin, E. T., Tan, F., Skidgel, R. A., Turner, A. J., and Hooper, N. M. (2003). The ectodomain shedding of angiotensin-converting enzyme is independent of its localisation in lipid rafts. J. Cell Sci. 116, 3079-3087. doi: 10.1242/jcs.00626

Plum, L. M., Rink, L., and Haase, H. (2010). The essential toxin: impact of zinc on human health. Int. J. Environ. Res. Public health 7, 1342-1365. doi: 10.3390/ijerph7041342

Pushie, M. J., Pickering, I. J., Martin, G. R., Tsutsui, S., Jirik, F. R., and George, G. N. (2011). Prion protein expression level alters regional copper, iron and zinc content in the mouse brain. Metallomics 3, 206-214. doi: 10.1039/c0mt00037j

Renner, M., Lacor, P. N., Velasco, P. T., Xu, J., Contractor, A., Klein, W. L., et al. (2010). Deleterious effects of amyloid beta oligomers acting as an extracellular scaffold for mGluR5. Neuron 66, 739-754. doi: 10.1016/j.neuron.2010.04.029

Rushworth, J. V., Griffiths, H. H., Watt, N. T., and Hooper, N. M. (2013). Prion protein-mediated toxicity of amyloid- $\beta$ oligomers requires lipid rafts and the transmembrane LRP1. J. Biol. Chem. 288, 8935-8951. doi: 10.1074/jbc.M112.400358

Rushworth, J. V., and Hooper, N. M. (2010). Lipid rafts: linking Alzheimer's amyloid- $\beta$ production, aggregation, and toxicity at neuronal membranes. Int. J. Alzheimers Dis. 2011, 603052. doi: 10.4061/2011/603052

Saito, T., Takahashi, K., Nakagawa, N., Hosokawa, T., Kurasaki, M., Yamanoshita, O., et al. (2000). Deficiencies of hippocampal Zn and ZnT3 accelerate brain aging of Rat. Biochem. Biophys. Res. Commun. 279, 505-511. doi: 10.1006/bbrc. 2000.3946

Sales, N., Rodolfo, K., Hassig, R., Faucheux, B., Di Giamberardino, L., and Moya, K. L. (1998). Cellular prion protein localization in rodent and primate brain. Eur. J. Neurosci. 10, 2464-2471. doi: 10.1046/j.1460-9568.1998.00258.x

Schmitt-Ulms, G., Ehsani, S., Watts, J. C., Westaway, D., and Wille, H. (2009). Evolutionary descent of prion genes from the ZIP family of metal ion transporters. PLoS ONE 4:e7208. doi: 10.1371/journal.pone.0007208

Sensi, S. L., Paoletti, P., Bush, A. I., and Sekler, I. (2009). Zinc in the physiology and pathology of the CNS. Nat. Rev. Neurosci. 10, 780-791. doi: 10.1038/nrn2734

Singh, N., Haldar, S., Tripathi, A. K., McElwee, M. K., Horback, K., and Beserra, A. (2014). Iron in neurodegenerative disorders of protein misfolding: a case of prion disorders and Parkinson's disease. Antioxid. Redox Signal. 21, 471-484. doi: 10.1089/ars.2014.5874

Solis, G. P., Malaga-Trillo, E., Plattner, H., and Stuermer, C. A. (2010). Cellular roles of the prion protein in association with reggie/flotillin microdomains. Front. Biosci. 15, 1075-1085. doi: 10.2741/3662

Stellato, F., Spevacek, A., Proux, O., Minicozzi, V., Millhauser, G., and Morante, S. (2011). Zinc modulates copper coordination mode in prion protein octa-repeat subdomains. Eur. Biophys. J. 40, 1259-1270. doi: 10.1007/s00249-011-0713-4

Stys, P. K., You, H., and Zamponi, G. W. (2012). Copper-dependent regulation of NMDA receptors by cellular prion protein: implications for neurodegenerative disorders. J. Physiol. 590, 1357-1368. doi: 10.1113/jphysiol.2011.225276

Szewczyk, B. (2013). Zinc homeostasis and neurodegenerative disorders. Front. Aging Neurosci. 5:33. doi: 10.3389/fnagi.2013.00033

Taylor, D. R., and Hooper, N. M. (2007). The low-density lipoprotein receptorrelated protein 1 (LRP1) mediates the endocytosis of the cellular prion protein. Biochem. J. 402, 17-23. doi: 10.1042/BJ20061736
Taylor, D. R., Watt, N. T., Perera, W. S., and Hooper, N. M. (2005). Assigning functions to distinct regions of the $\mathrm{N}$-terminus of the prion protein that are involved in its copper-stimulated, clathrin-dependent endocytosis. J. Cell Sci. 118, 5141-5153. doi: $10.1242 /$ jcs. 02627

Toth, K. (2011). Zinc in neurotransmission. Annu. Rev. Nutr. 31, 139-153. doi: 10.1146/annurev-nutr-072610-145218

Um, J. W., Kaufman, A. C., Kostylev, M., Heiss, J. K., Stagi, M., Takahashi, H., et al. (2013). Metabotropic glutamate receptor 5 is a coreceptor for Alzheimer A $\beta$ oligomer bound to cellular prion protein. Neuron 79, 887-902. doi: 10.1016/j.neuron.2013.06.036

Um, J. W., Nygaard, H. B., Heiss, J. K., Kostylev, M. A., Stagi, M., Vortmeyer, A., et al. (2012). Alzheimer amyloid- $\beta$ oligomer bound to postsynaptic prion protein activates Fyn to impair neurons. Nat. Neurosci. 15, 1227-1235. doi: 10.1038/nn.3178

Wang, F., Dufner-Beattie, J., Kim, B. E., Petris, M. J., Andrews, G., and Eide, D. J. (2004). Zinc-stimulated endocytosis controls activity of the mouse ZIP1 and ZIP3 zinc uptake transporters. J. Biol. Chem. 279, 24631-24639. doi: 10.1074/jbc.M400680200

Watt, N. T., Griffiths, H. H., and Hooper, N. M. (2013). Neuronal zinc regulation and the prion protein. Prion 7, 203-208. doi: 10.4161/pri.24503

Watt, N. T., Taylor, D. R., Kerrigan, T. L., Griffiths, H. H., Rushworth, J. V., Whitehouse, I. J., et al. (2012). Prion protein facilitates uptake of zinc into neuronal cells. Nat. Commun. 3, 1134. doi: 10.1038/ncomms 2135

Watt, N. T., Whitehouse, I. J., and Hooper, N. M. (2010). The role of zinc in Alzheimer's disease. Int. J. Alzheimers Dis. 2011:971021. doi: $10.4061 / 2011 / 971021$

Whitehouse, I. J., Jackson, C. D., Turner, A. J., and Hooper, N. M. (2010). Prion protein is reduced in aging and in sporadic but not in familial Alzheimer's disease. J. Alzheimers Dis. 22, 1023-1031. doi: 10.3233/JAD-2010-101071

Whitehouse, I. J., Miners, J. S., Glennon, E. B., Kehoe, P. G., Love, S., Kellett, K. A., et al. (2013). Prion protein is decreased in Alzheimer's brain and inversely correlates with BACE1 activity, amyloid- $\beta$ levels and Braak stage. PLoS ONE 8:e59554. doi: 10.1371/journal.pone.0059554

Williamson, R., Usardi, A., Hanger, D. P., and Anderton, B. H. (2008). Membranebound $\beta$-amyloid oligomers are recruited into lipid rafts by a Fyn-dependent mechanism. FASEB J. 22, 1552-1559. doi: 10.1096/fj.07-9766com

Willmann, R., Pun, S., Stallmach, L., Sadasivam, G., Santos, A. F., Caroni, P., et al. (2006). Cholesterol and lipid microdomains stabilize the postsynapse at the neuromuscular junction. EMBO J. 25, 4050-4060. doi: 10.1038/sj.emboj.7601288

Wilson, M., Hogstrand, C., and Maret, W. (2012). Picomolar concentrations of free zinc(II) ions regulate receptor protein-tyrosine phosphatase $\beta$ activity. J. Biol. Chem. 287, 9322-9326. doi: 10.1074/jbc.C111.320796

Wong, B. X., Hung, Y. H., Bush, A. I., and Duce, J. A. (2014). Metals and cholesterol: two sides of the same coin in Alzheimer's disease pathology. Front. Aging Neurosci. 6:91. doi: 10.3389/fnagi.2014.00091

Wong, C. P., Magnusson, K. R., and Ho, E. (2013). Increased inflammatory response in aged mice is associated with age-related zinc deficiency and zinc transporter dysregulation. J. Nutr. Biochem. 24, 353-359. doi: 10.1016/j.jnutbio.2012.07.005

Conflict of Interest Statement: The authors declare that the research was conducted in the absence of any commercial or financial relationships that could be construed as a potential conflict of interest.

Received: 25 June 2014; paper pending published: 08 July 2014; accepted: 05 August 2014; published online: 20 August 2014.

Citation: Watt NT, Griffiths HH and Hooper NM (2014) Lipid rafts: linking prion protein to zinc transport and amyloid- $\beta$ toxicity in Alzheimer's disease. Front. Cell Dev. Biol. 2:41. doi: 10.3389/fcell.2014.00041

This article was submitted to Cell Death and Survival, a section of the journal Frontiers in Cell and Developmental Biology.

Copyright (C) 2014 Watt, Griffiths and Hooper. This is an open-access article distributed under the terms of the Creative Commons Attribution License (CC BY). The use, distribution or reproduction in other forums is permitted, provided the original author(s) or licensor are credited and that the original publication in this journal is cited, in accordance with accepted academic practice. No use, distribution or reproduction is permitted which does not comply with these terms. 